Supporting information for:

\title{
Synergetic Hydroxyl Radical Oxidation with Atomic Hydrogen Reduction Lowers Organochlorines Conversion Barrier and Potentiates Effective Contaminants Mineralization
}

Jun Zhang ${ }^{a}$, Gong Zhang ${ }^{a}$, Huachun Lan ${ }^{a}$, Jiuhui Qu ${ }^{a, b}$, Huijuan Liu ${ }^{a^{*}}$

a, Center for Water and Ecology, State Key Joint Laboratory of Environment Simulation and Pollution Control, School of Environment, Tsinghua University, Beijing 100084, China b, Key Laboratory of Drinking Water Science and Technology, Research Center for Eco-Environmental Sciences, Chinese Academy of Sciences, Beijing 100085, China

* Corresponding Author.

(H. Liu) Phone/Fax: +86-10-62793185; E-mail: hjliu@tsinghua.edu.cn. 
Supporting information includes:

16 Pages

13 Figures

1 Tables 
Table S1. Characteristics of the printing and dyeing enterprise and pharmaceutical enterprise effluents.

\begin{tabular}{|c|c|c|c|c|c|c|}
\hline & Parameters & $\begin{array}{c}\text { DOC } \\
(\mathrm{mg} / \mathrm{L})\end{array}$ & $\mathrm{pH}$ & $\begin{array}{c}\mathrm{DO} \\
(\mathrm{mg} / \mathrm{L})\end{array}$ & $\begin{array}{l}\text { Conductivity } \\
\qquad(\mathrm{mS} / \mathrm{cm})\end{array}$ & $\begin{array}{c}\text { Total } \\
\text { nitrogen } \\
(\mathrm{mg} / \mathrm{L})\end{array}$ \\
\hline $\begin{array}{l}\text { Printing and } \\
\text { dyeing } \\
\text { enterprise }\end{array}$ & Values & $\sim 71$ & $\sim 8.92$ & $\sim 8.32$ & $\sim 1.29$ & $\sim 174.21$ \\
\hline $\begin{array}{c}\text { Pharmaceutical } \\
\text { enterprise }\end{array}$ & Values & $\sim 55$ & $\sim 8.05$ & $\sim 8.76$ & $\sim 11.98$ & $\sim 111.07$ \\
\hline
\end{tabular}

The printing and dyeing enterprise effluent was taken from Wuxi Haijiang Printing and Dyeing Co., LTD. Jiangsu Province, China; and the pharmaceutical enterprise effluent was taken from Beijing Jialin Pharmaceutical Co. LTD. Beijing, China. 

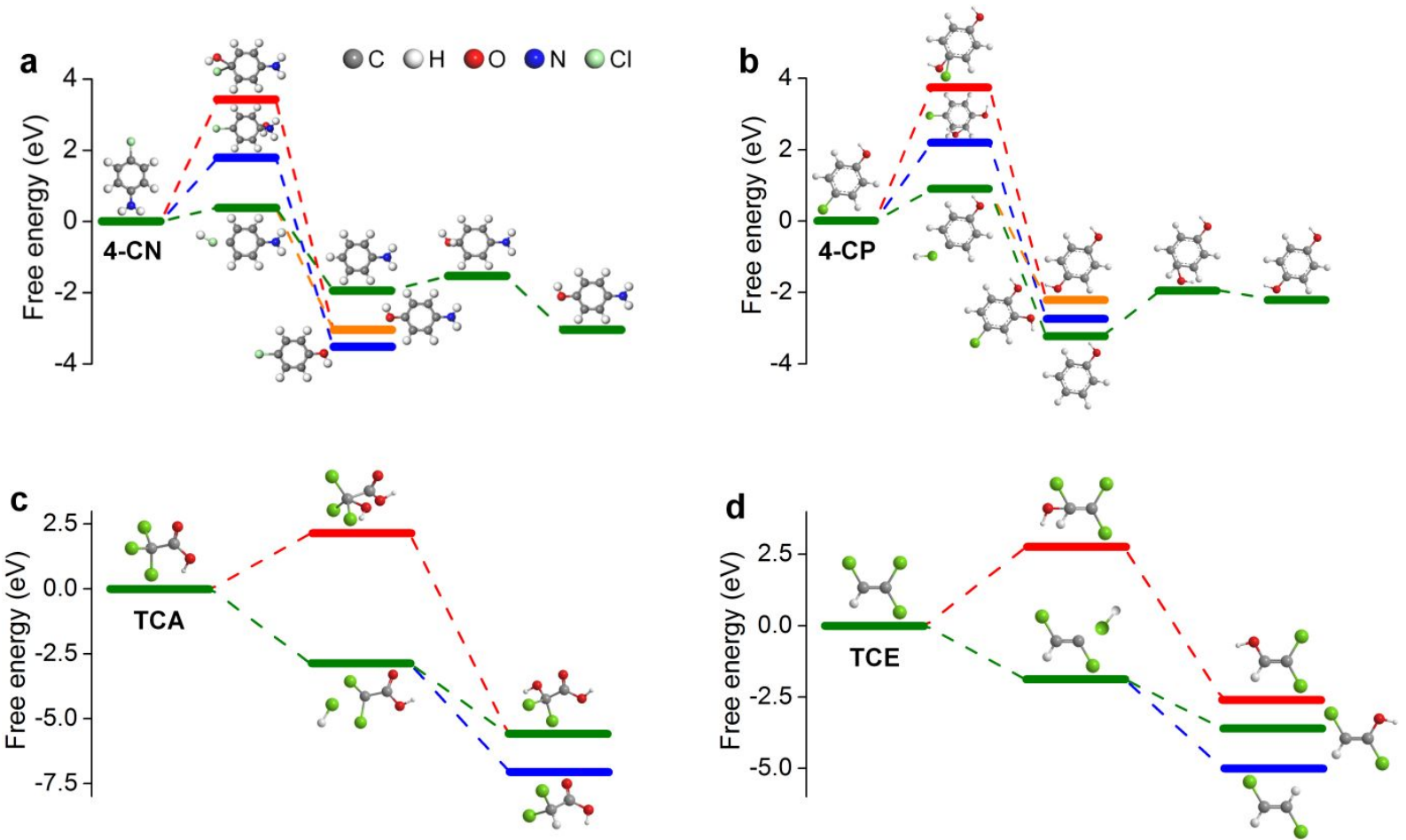

Figure S1. Free-energy diagram for the degradation of (a) p-chloroaniline, (b) p-chlorophenol, (c) trichloroacetic acid, and (d) trichloroethylene via the alone oxidation by $\bullet \mathrm{OH}$ and the redox synergy of $\mathrm{H}^{*}$ and $\bullet \mathrm{OH}$. 


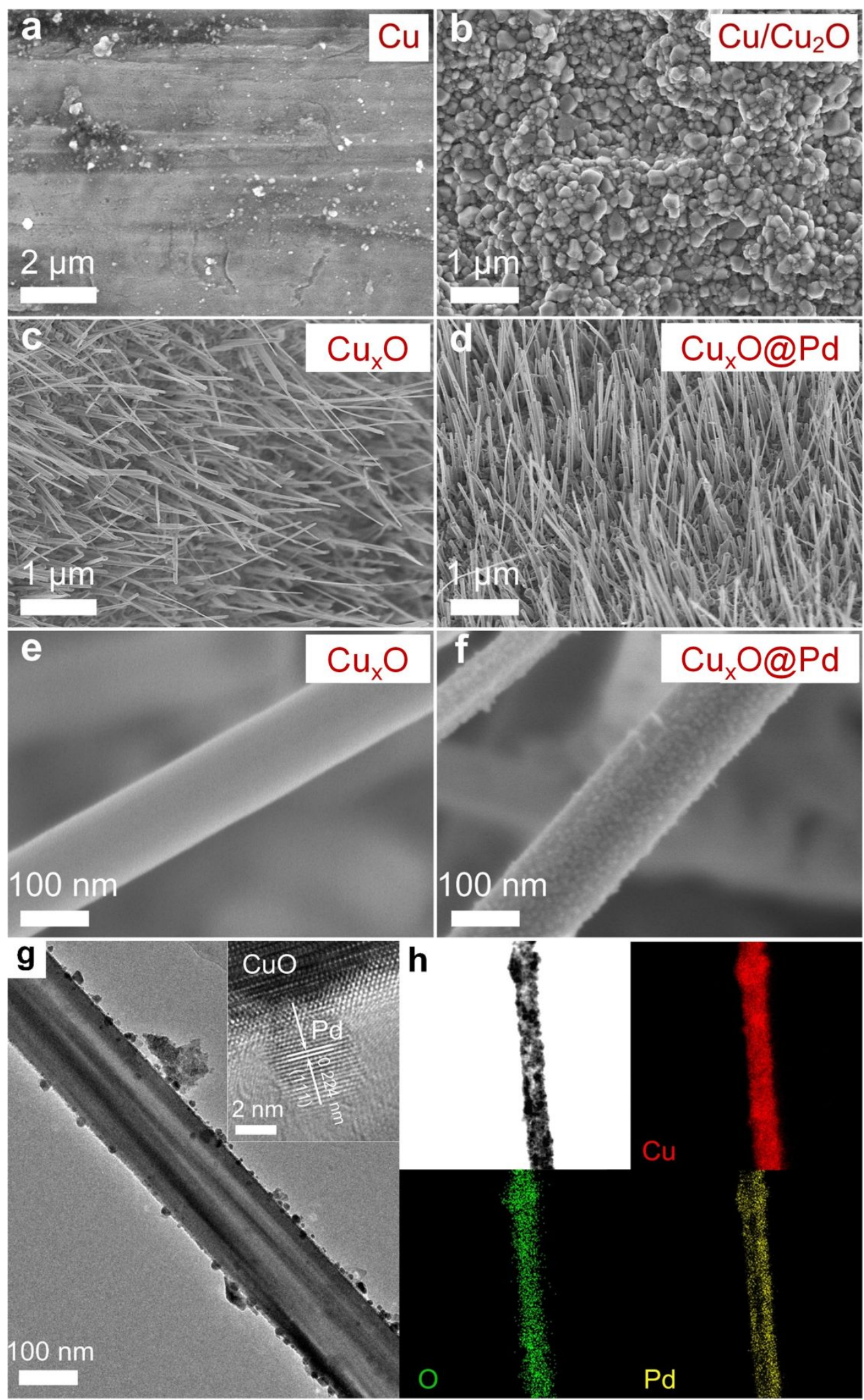

Figure S2. $\mathrm{SEM}$ images of (a) $\mathrm{Cu}$ foil, (b) $\mathrm{Cu} / \mathrm{Cu}_{2} \mathrm{O}$, (c) $\mathrm{Cu} / \mathrm{Cu}_{2} \mathrm{O} / \mathrm{CuO}$ and (d) $\mathrm{Cu} / \mathrm{Cu}_{2} \mathrm{O} / \mathrm{CuO} / \mathrm{Pd}$;

High-resolution SEM images of (e) $\mathrm{Cu} / \mathrm{Cu}_{2} \mathrm{O} / \mathrm{CuO}$ and (f) $\mathrm{Cu} / \mathrm{Cu}_{2} \mathrm{O} / \mathrm{CuO} / \mathrm{Pd}$; (g) $\mathrm{TEM}$ and HRTEM images and (h) EDX mapping images of $\mathrm{Cu} / \mathrm{Cu}_{2} \mathrm{O} / \mathrm{CuO} / \mathrm{Pd}$. 

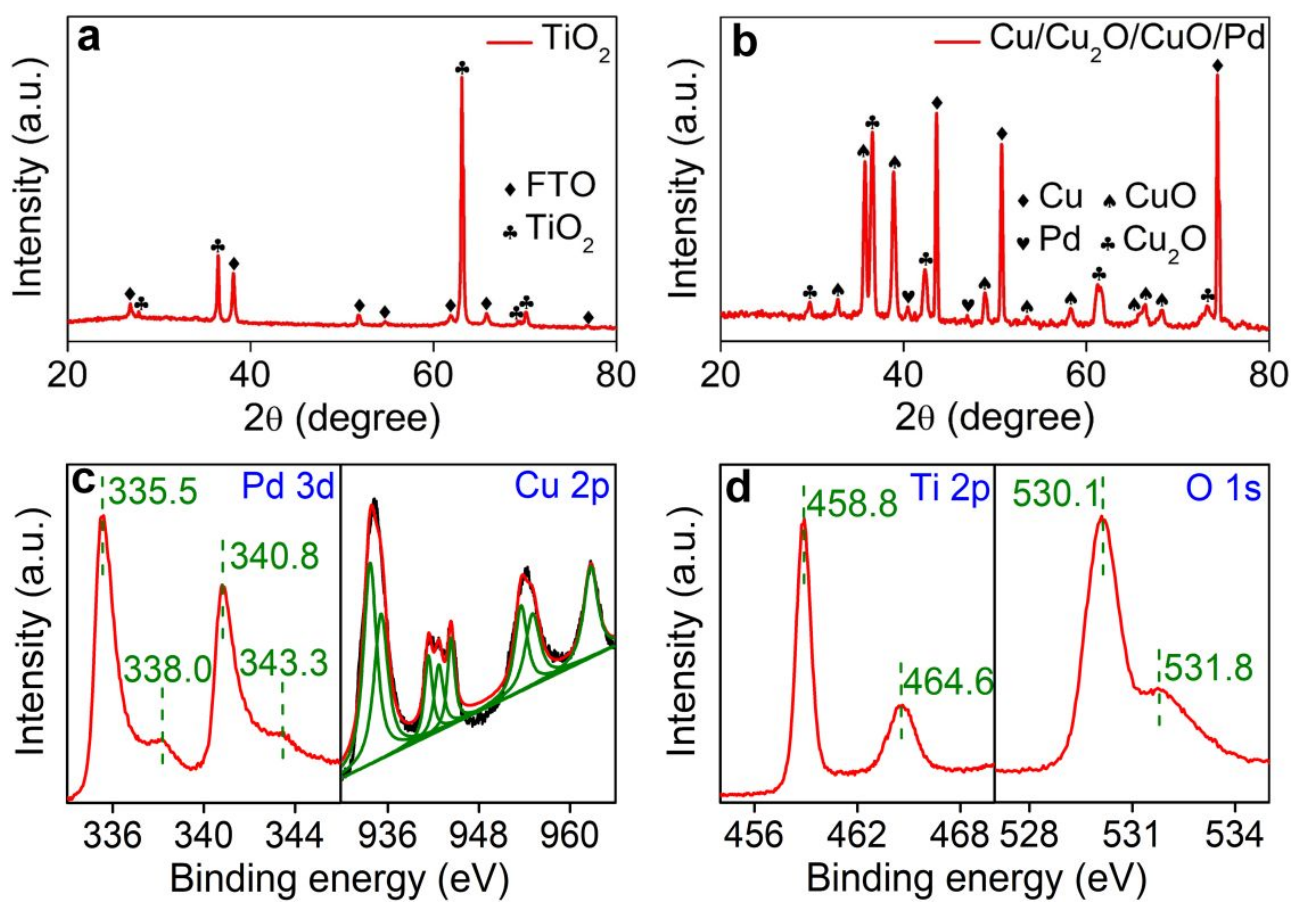

Figure S3. XRD patterns of (a) $\mathrm{TiO}_{2}$ photoanode and (b) $\mathrm{Cu} / \mathrm{Cu}_{2} \mathrm{O} / \mathrm{CuO} / \mathrm{Pd}$ photocathode; High-resolution XPS spectra of (c) $\mathrm{Cu} / \mathrm{Cu}_{2} \mathrm{O} / \mathrm{CuO} / \mathrm{Pd}$ photocathode and (d) $\mathrm{TiO}_{2}$ photoanode. 
a

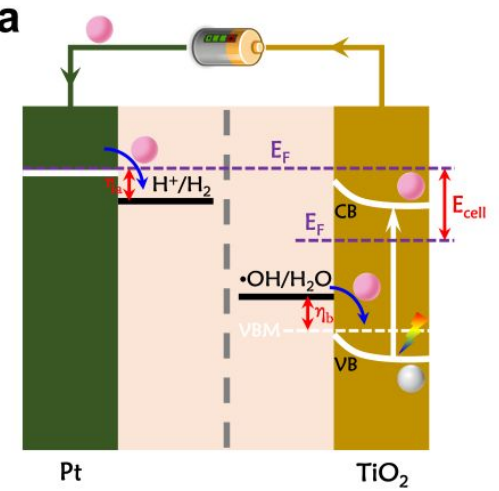

b

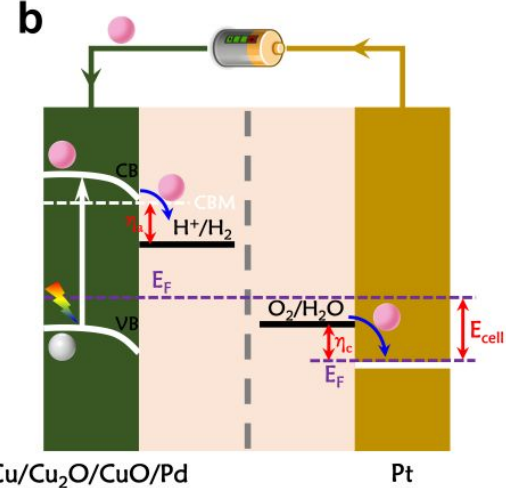

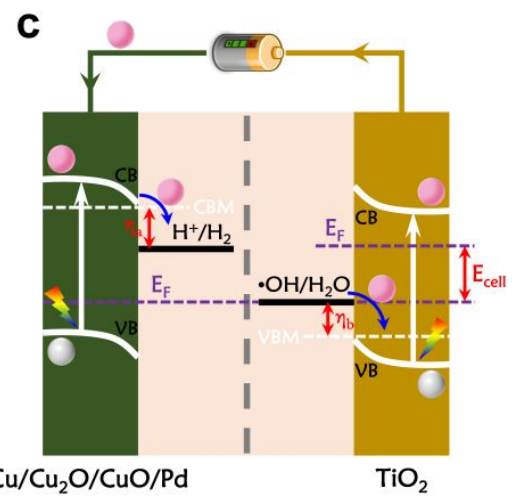

Figure S4. Schematic reaction mechanisms of $\mathrm{TiO}_{2}-\mathrm{Pt}, \mathrm{Pt}-\mathrm{Cu} / \mathrm{Cu}_{2} \mathrm{O} / \mathrm{CuO} / \mathrm{Pd}$, and $\mathrm{TiO}_{2}-\mathrm{Cu} / \mathrm{Cu}_{2} \mathrm{O} / \mathrm{CuO} / \mathrm{Pd} \mathrm{PEC}$ systems. Illustrating why the use of dual photoelectrodes can decrease the overall cell voltage needed to operate the entire cell, enhance photo-responses, and increase photocurrent density. VB was the valence band; CB was the conduction band; VBM was the valence band maximum; $\mathrm{CBM}$ was the valence band minimum; $\mathrm{E}_{\mathrm{F}}$ was the Fermi level; $\mathrm{E}_{\text {cell }}$ was the bias voltage needed to operate the overall cell; $\eta_{\mathrm{a}}$ was the cathodic overpotential for $\mathrm{H}^{+} / \mathrm{H}_{2} ; \eta_{\mathrm{b}}$ was the anodic overpotential for $\bullet \mathrm{OH} / \mathrm{H}_{2} \mathrm{O} ; \eta_{\mathrm{c}}$ was the anodic overpotential for $\mathrm{O}_{2} / \mathrm{H}_{2} \mathrm{O}$. 

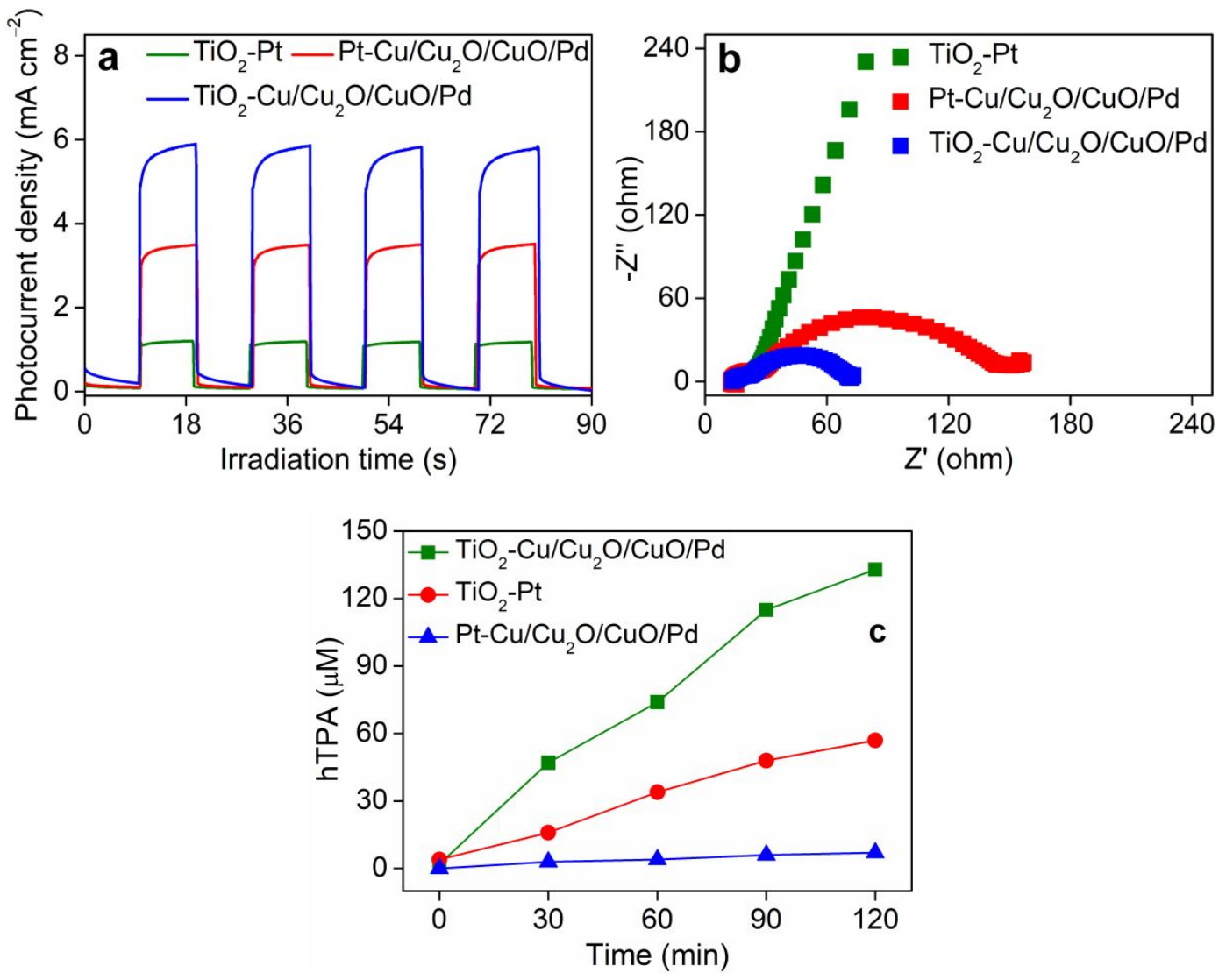

Figure S5. (a) Transient photocurrents, (b) EIS curves and (c) the cumulative concentrations of - $\mathrm{OH}$ over time of $\mathrm{TiO}_{2}-\mathrm{Pt}, \mathrm{Pt}-\mathrm{Cu} / \mathrm{Cu}_{2} \mathrm{O} / \mathrm{CuO} / \mathrm{Pd}$, and $\mathrm{TiO}_{2}-\mathrm{Cu} / \mathrm{Cu}_{2} \mathrm{O} / \mathrm{CuO} / \mathrm{Pd} \mathrm{PEC}$ systems. Experimental conditions: electrolyte $\left(50 \mathrm{mM} \mathrm{Na} \mathrm{SO}_{4}\right)$, applied potential ( $0.3 \mathrm{~V}$ vs. RHE), frequency range $(0.1 \mathrm{~Hz}-100 \mathrm{kHz})$, disturbance voltage $(10 \mathrm{mV})$, temperature $\left(25{ }^{\circ} \mathrm{C}\right)$, Ar-saturated, in the light irradiation. 

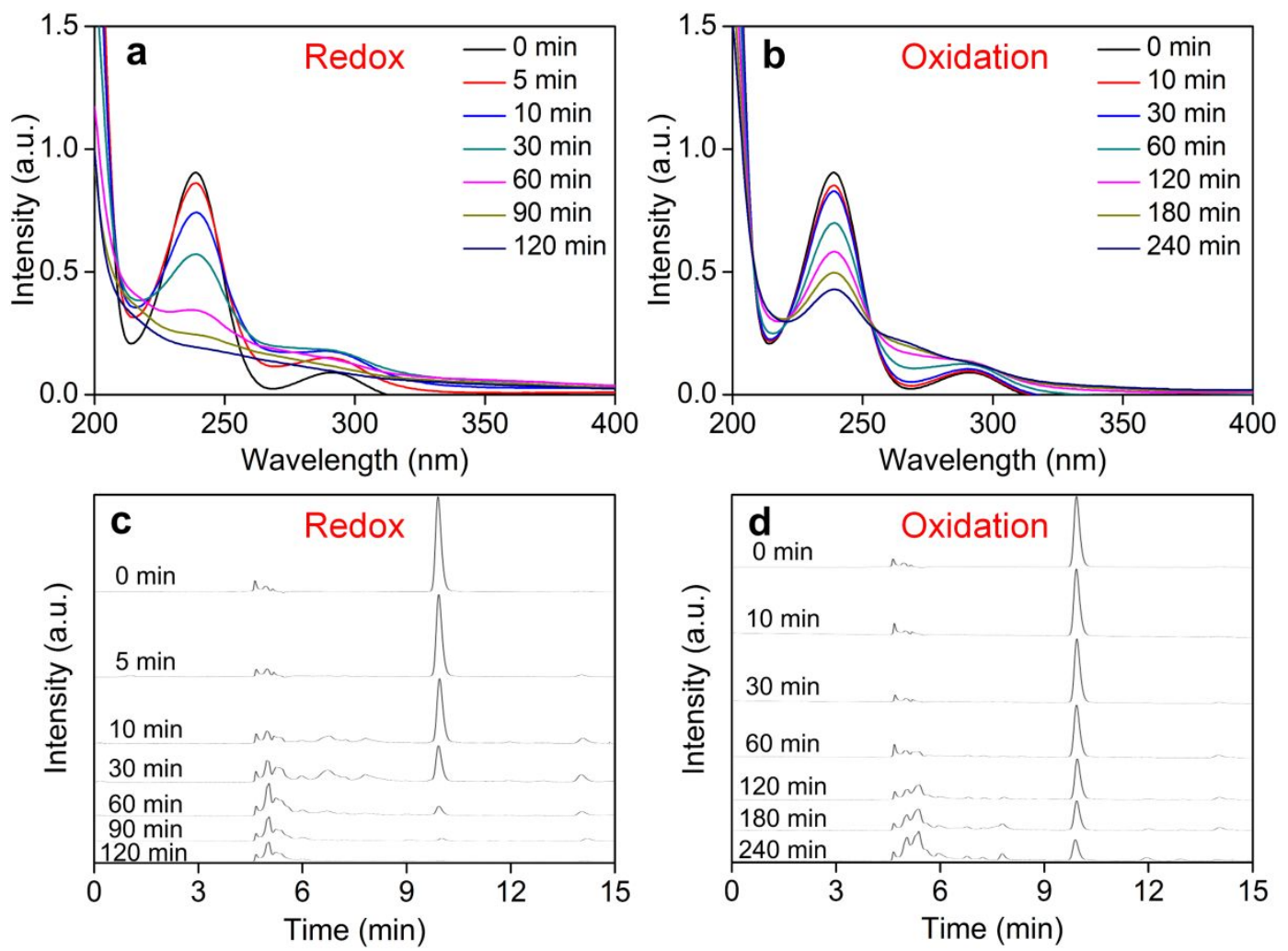

Figure S6. $(a-b)$ UV-Vis absorption spectra and (c-d) HPLC finger-print maps of 4-CN removal in the synchronous redox process based on the synergy between $\mathrm{H}^{*}$ and $\cdot \mathrm{OH}$ and the alone oxidation process with only $\bullet \mathrm{OH}$, respectively. Experimental conditions: electrolyte $(50 \mathrm{mM}$ $\left.\mathrm{Na}_{2} \mathrm{SO}_{4}\right), 4-\mathrm{CN}$ concentration $(5 \mathrm{mg} \mathrm{L}-1)$, applied potential $(0.3 \mathrm{~V}$ vs. RHE $)$, temperature $\left(25^{\circ} \mathrm{C}\right)$, Ar-saturated, in the light irradiation. 


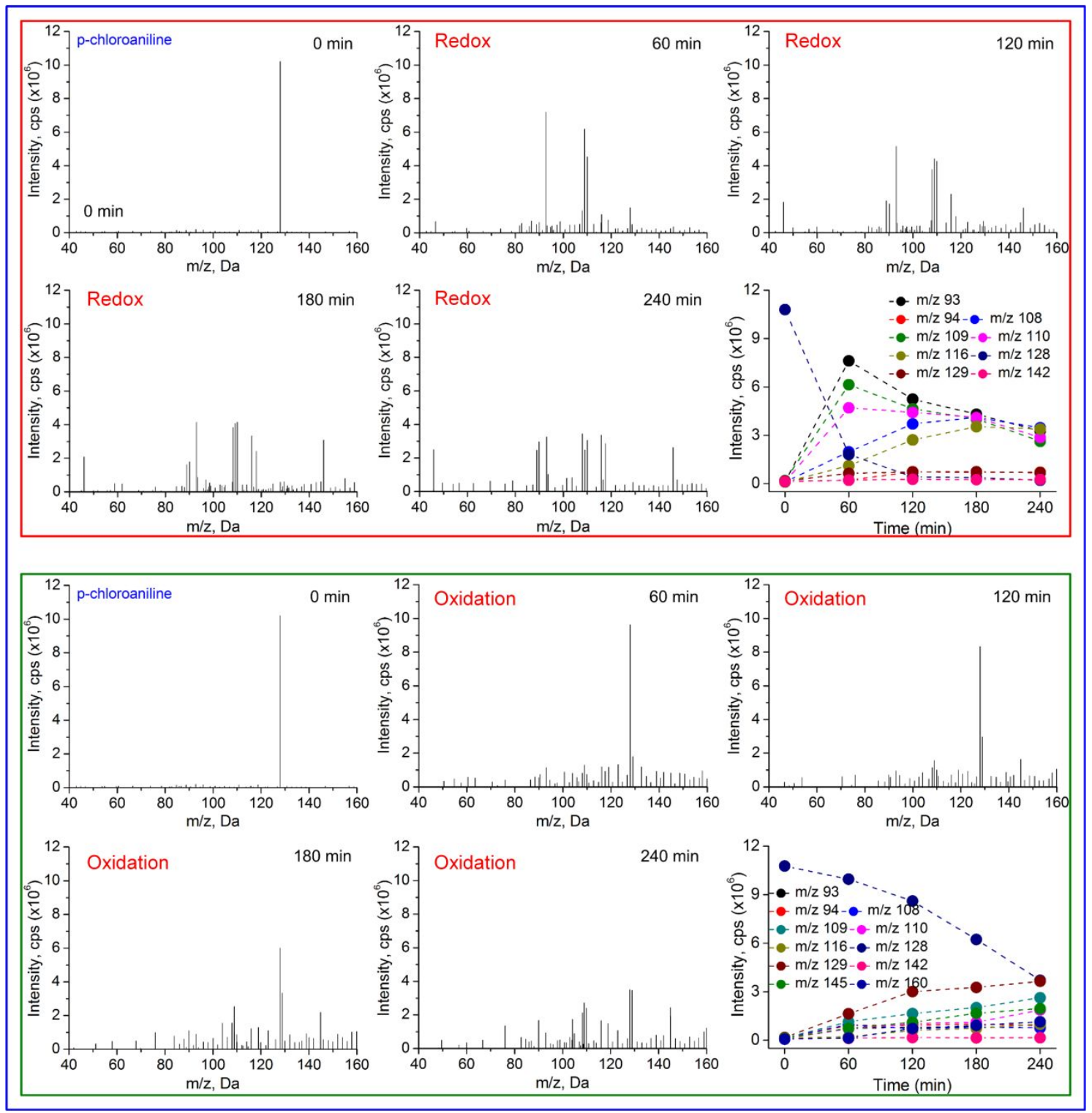

Figure S7. The generated intermediates in the process of $4-\mathrm{CN}$ degradation detected by HPLC-QTOF-MS instrument for the synchronous redox process based on the synergy between $\mathrm{H}^{*}$ and $\cdot \mathrm{OH}$ and the alone oxidation process with only $\bullet \mathrm{OH}$, respectively. Experimental conditions: electrolyte $\left(50 \mathrm{mM} \mathrm{Na} 2 \mathrm{SO}_{4}\right), 4-\mathrm{CN}$ concentration $\left(5 \mathrm{mg} \mathrm{L}^{-1}\right)$, applied potential $(0.3 \mathrm{~V}$ vs. RHE), temperature $\left(25^{\circ} \mathrm{C}\right)$, Ar-saturated, in the light irradiation. 

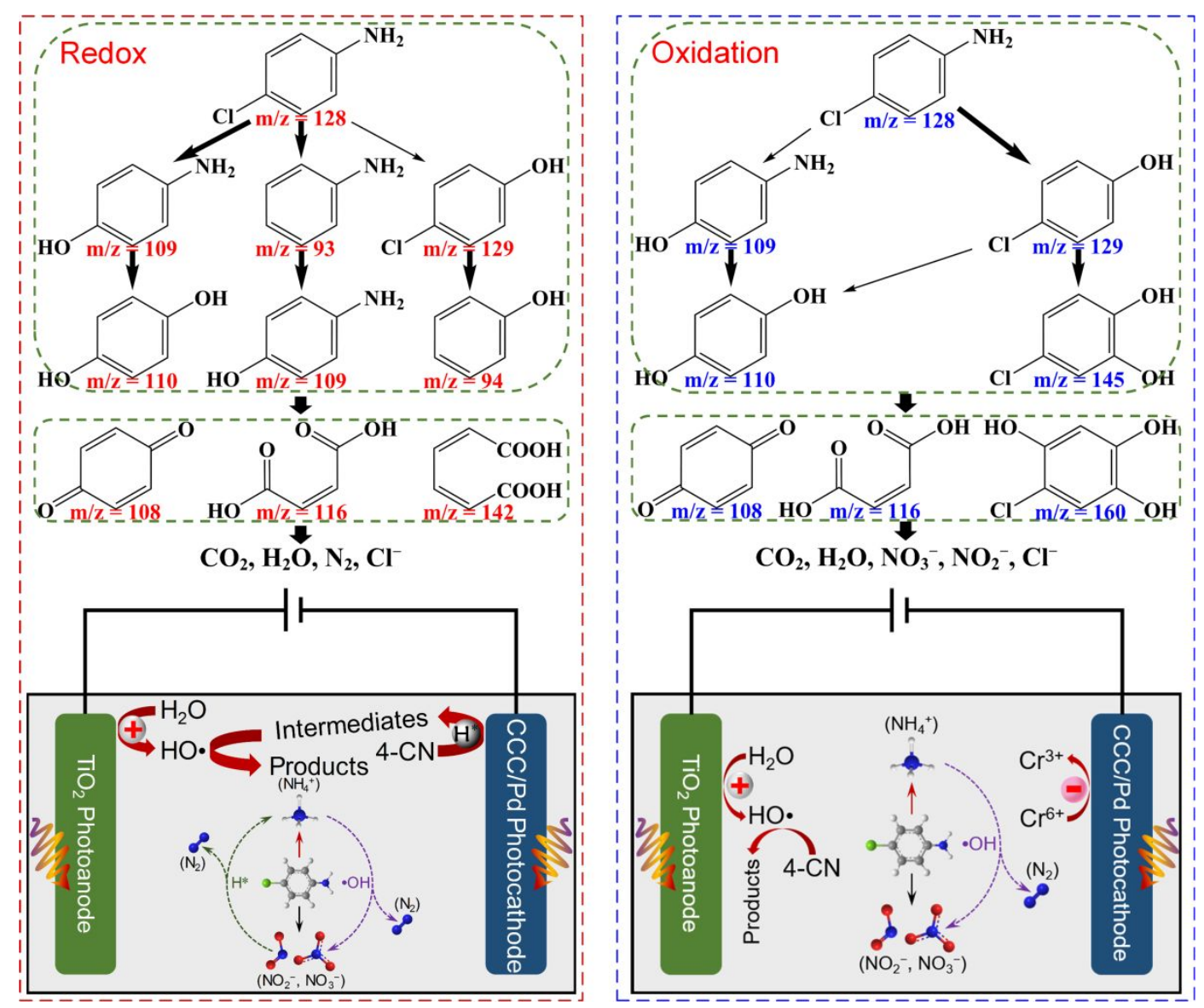

Figure S8. The degradation pathways of $4-\mathrm{CN}$ and schematic reaction mechanism in the synchronous redox process based on the synergy between $\mathrm{H}^{*}$ and $\bullet \mathrm{OH}$ and the alone oxidation process with only $\cdot \mathrm{OH}$, respectively. Experimental conditions: electrolyte $\left(50 \mathrm{mM} \mathrm{Na} 2 \mathrm{SO}_{4}\right)$, 4-CN concentration $\left(5 \mathrm{mg} \mathrm{L}^{-1}\right)$, applied potential $(0.3 \mathrm{~V}$ vs. $\mathrm{RHE})$, temperature $\left(25{ }^{\circ} \mathrm{C}\right)$, Ar-saturated, in the light irradiation. 

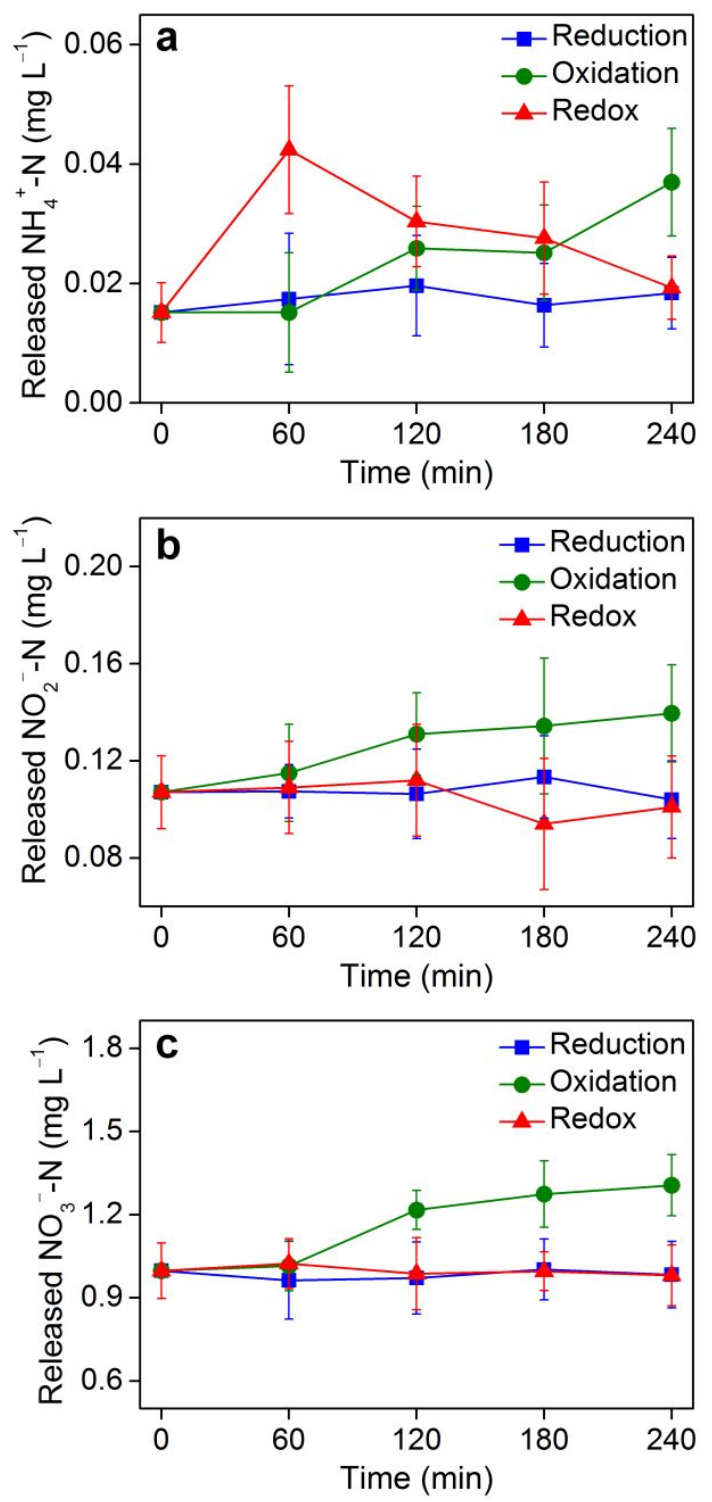

Figure S9. (a) The $\mathrm{NH}_{4}{ }^{+}$changes, (b) $\mathrm{NO}_{3}{ }^{-}$changes and (c) $\mathrm{NO}_{2}^{-}$changes over time in the synchronous redox process based on the synergy between $\mathrm{H}^{*}$ and $\bullet \mathrm{OH}$, the alone oxidation process with only $\bullet \mathrm{OH}$, and the alone reduction process with only $\mathrm{H}^{*}$, respectively. Experimental conditions: electrolyte $\left(50 \mathrm{mM} \mathrm{Na} 2 \mathrm{SO}_{4}\right), 4-\mathrm{CN}$ concentration $\left(5 \mathrm{mg} \mathrm{L}^{-1}\right)$, applied potential $(0.3 \mathrm{~V}$ vs. RHE), temperature $\left(25^{\circ} \mathrm{C}\right)$, Ar-saturated, in the light irradiation. 

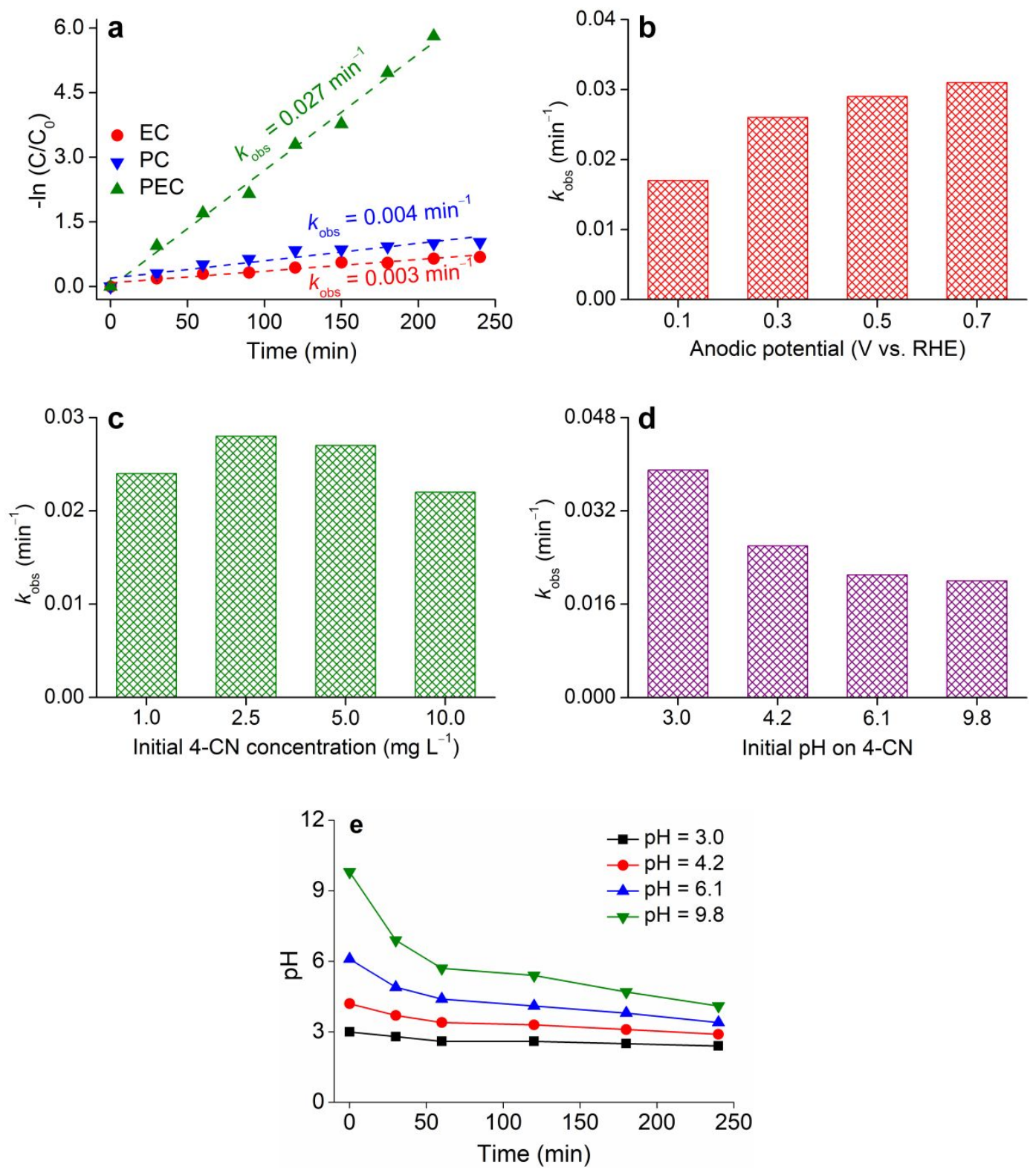

Figure S10. (a) The comparison of the EC, PC, and $\mathrm{PEC}$ processes in $\mathrm{TiO}_{2}-\mathrm{Cu}_{\mathrm{x}} \mathrm{O} @ \mathrm{Pd}$ system for 4-CN removal; $(b-d)$ The impacts of the different bias voltage, different initial concentration of 4-CN, and different initial $\mathrm{pH}$ on $4-\mathrm{CN}$ for $4-\mathrm{CN}$ removal in $\mathrm{TiO}_{2}-\mathrm{Cu}_{\mathrm{x}} \mathrm{O} @ \mathrm{Pd} \mathrm{PEC}$ system; (e) The $\mathrm{pH}$ changes during 4-CN removal reaction. Experimental conditions: electrolyte $(50 \mathrm{mM}$ $\left.\mathrm{Na}_{2} \mathrm{SO}_{4}\right)$, temperature $\left(25^{\circ} \mathrm{C}\right)$, Ar-saturated, in the light irradiation. 

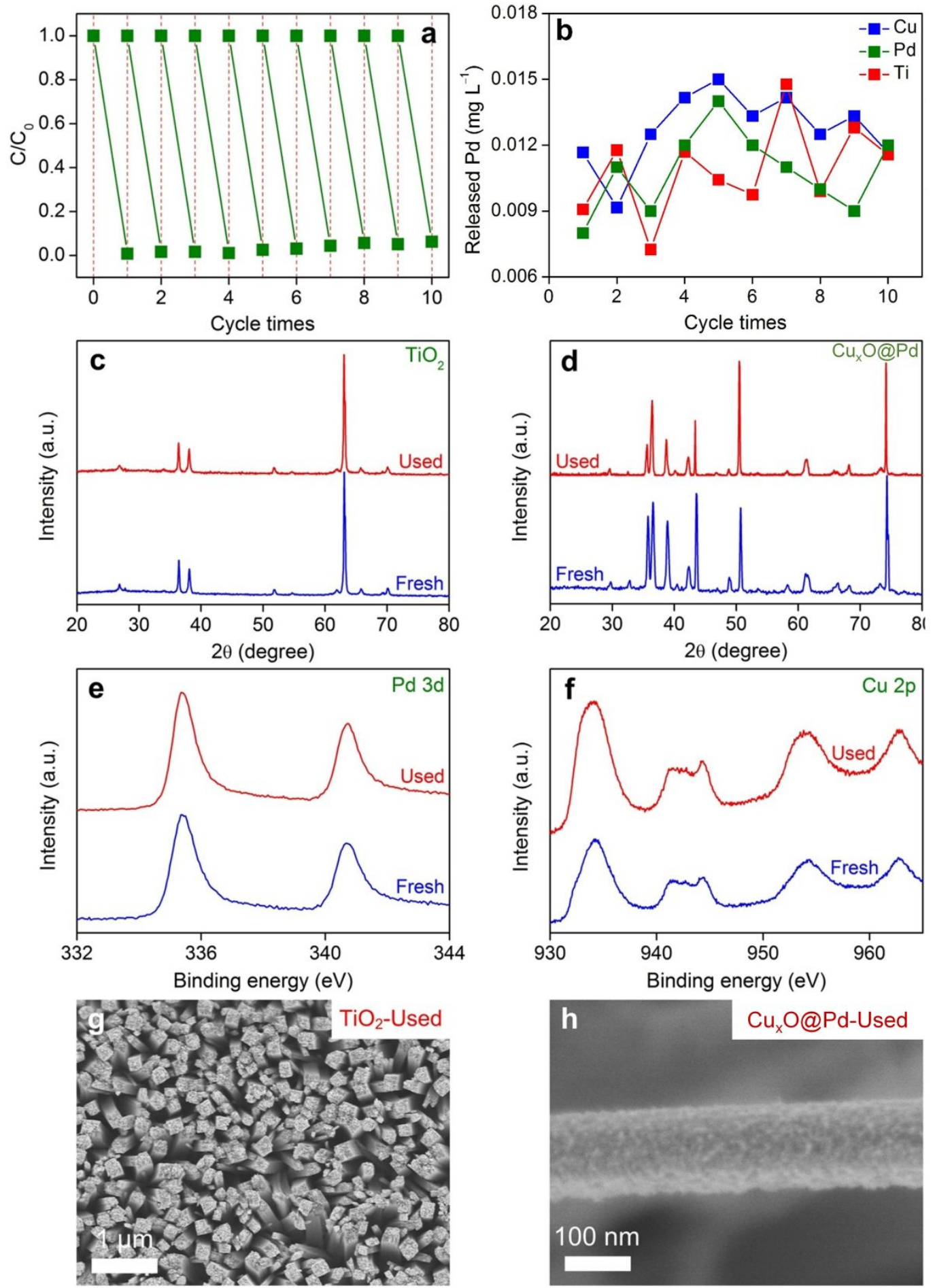

Figure S11. (a) Recycling runs of 4-CN removal, (b) released $\mathrm{Ti}$, $\mathrm{Pd}$ and $\mathrm{Cu}$ contents, (c- d) XRD patterns, $(e-f)$ XPS spectra and $(\mathrm{g}-\mathrm{h})$ SEM images for fresh and used of $\mathrm{TiO}_{2}$ and $\mathrm{Cu}_{\mathrm{x}} \mathrm{O} @ \mathrm{Pd}$ in $\mathrm{TiO}_{2}-\mathrm{Cu}_{\mathrm{x}} \mathrm{O} @ \mathrm{Pd} \mathrm{PEC}$ system. Experimental conditions: electrolyte $(50 \mathrm{mM}$ $\left.\mathrm{Na}_{2} \mathrm{SO}_{4}\right), 4-\mathrm{CN}$ concentration $\left(5 \mathrm{mg} \mathrm{L}^{-1}\right)$, applied potential $(0.3 \mathrm{~V}$ vs. RHE $)$, temperature $\left(25^{\circ} \mathrm{C}\right)$, Ar-saturated, in the light irradiation. 


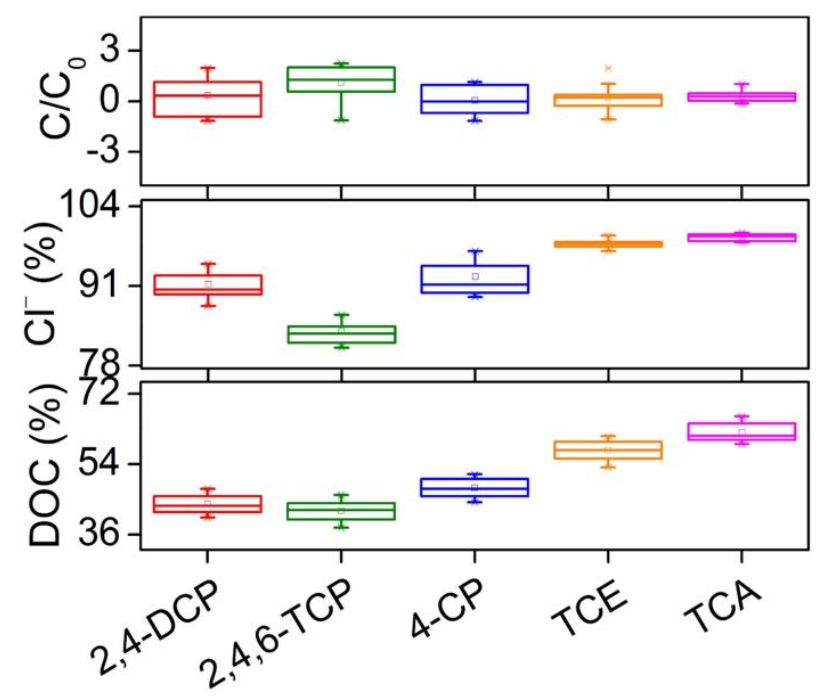

Figure S12. Degradation efficiencies, released $\mathrm{Cl}^{-}$contents and DOC removal efficiencies of five different chlorinated organic contaminants in $\mathrm{TiO}_{2}-\mathrm{Cu}_{\mathrm{x}} \mathrm{O} @ \mathrm{Pd}$ PEC system. Experimental conditions: electrolyte ( $\left.50 \mathrm{mM} \mathrm{Na} \mathrm{SO}_{4}\right)$, chlorinated organic contaminants concentration (5 $\mathrm{mg}$ $\left.\mathrm{L}^{-1}\right)$, applied potential $\left(0.3 \mathrm{~V}\right.$ vs. RHE), temperature $\left(25^{\circ} \mathrm{C}\right)$, Ar-saturated, in the light irradiation. 


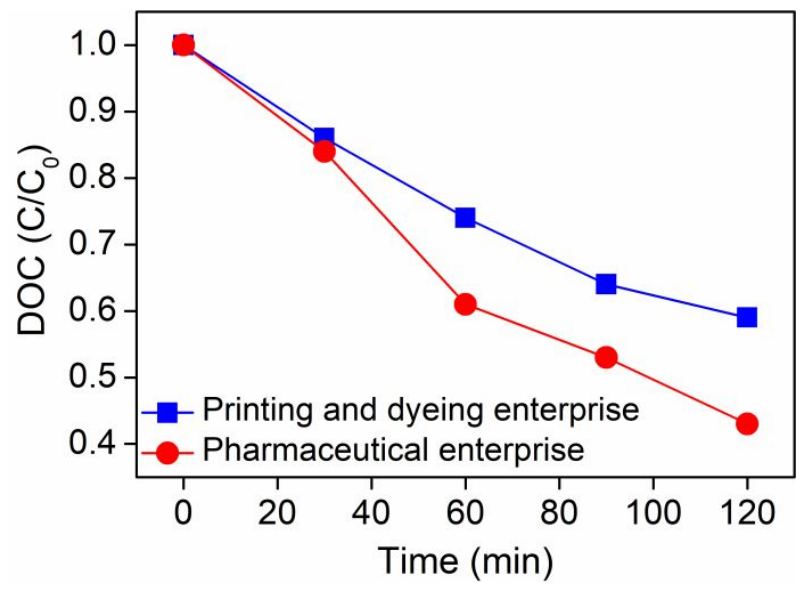

Figure S13. DOC removal efficiencies of two kinds of real industrial wastewater treated by PEC redox system. Experimental conditions: applied potential $\left(0.3 \mathrm{~V}\right.$ vs. RHE), temperature $\left(25^{\circ} \mathrm{C}\right)$, Ar-saturated, in the light irradiation. 